\title{
Effects of Brook Trout Predation on a Crayfish Population ${ }^{2}$
}

\author{
WALTER T. MOMOT ${ }^{2}$ \\ Department of Wildlife and Fisheries, The University of Michigan and the Institute for \\ Fisheries Research, Michigan Department of Conservation, Ann Arbor, Michigan
}

\begin{abstract}
A study was made of the effect of trout predation upon the crayfish population of a marl lake. The study provided a measurement of the efficiency of energy transfer between trophic levels in the lake and the assessment of the relative importance of fish predation as an interspecies interaction.

Trout fed only on crayfish less than one year old. Only trout greater than $229 \mathrm{~mm}$ in length fed extensively on crayfish. Trout predation accounted for the removal of less than $3 \%$ of the population of age-0.0 to 0.5-year crayfish during the period from June to January, and $16 \%$ of the population of age- 0.5 to 1.0 crayfish from January to May. Crayfish were an important part of the trout diet in midwinter and late summer. Age-0 crayfish which were much larger in midwinter than in summer constituted a greater percentage of the fish diet at these times. On an annual basis trout utilized only $2.9 \%$ of the total net production and only $4.2 \%$ of the available net production of crayfish biomass in the lake.

Substituting the trout predation rate for fishing mortality in Ricker's equilibrium yield equation, showed that a maximum yield of crayfish would be attained at two times the current rate of trout predation. Crayfish yield to the trout might be increased by introducing another smaller crayfish, $O$. propinquus, with the same reproductive potential as $O$. virilis.

Predation was not an important population control mechanism.
\end{abstract}

\section{INTRODUCTION}

One of the central problems of trophic ecology, is to define the pathway by which the primary production of an ecosystem is passed on to other organisms (Ivlev, 1961). In the trophic dynamics of any aquatic ecosystem, the myriads of organisms, mainly invertebrates, which make up the secondary level of production are of key importance as primary consumers. The interrelationships between secondary consumers and primary consumers are one of the key areas of study in trophic ecology. The principles governing these relationships are of primary importance in understanding the biological productivity of any ecosystem.

The small marl lakes of the Pigeon River Trout Research Area, of the Michigan Department of Conservation form outstanding natural laboratories for studies of trophic ecology. They have no outlets or inlets, a very restricted drainage area, and a fish population of a single species stocked at a constant rate. I selected one of these, West Lost Lake, to examine the influence of preda-

\footnotetext{
${ }^{1}$ The investigation was supported by Dingell-Johnson Project F-27-R Michigan and a predoctoral fellowship from the Institute for Fisheries Research.

2 Present Address: Department of Zoology and Entomology, The Ohio State University, Columbus, Ohio 43210 .
}

tion by brook trout, Salvelinus fontinalis (Mitchill), on the productivity of a population of crayfish, Orconectes virilis (Hagen) which is abundant in the lake. The limnological characteristics of West Lost Lake are described in Tanner (1960). It is located in Otsego Co., Mich. (R. 1W, T32N, SEC.3).

\section{MATERIALS AND METHODS}

The brook trout is the only species of fish present in West Lost Lake. Since there is no natural reproduction, fish averaging $126 \mathrm{~mm}$ in length are planted annually at a rate of 3,300 per surface hectare. The catch of all fishermen was examined by the staff of the Pigeon River Research Station. This census has provided data on the yield, age and growth, and food habits of the trout.

Estimates of trout population density were made each spring and fall during 1962 and 1963. The Petersen mark and recapture method was employed. Fish were collected with a d-c electro-fishing device described by Latta and Myers (1961).

Because of the care taken in techniques and in the redistribution of the fish through the area after handling and because of the short time between marking and recapture and population estimates are believed to be very accurate (W. C. Latta, personal com- 
munication). Similar estimates are described in Latta (1962).

Brook trout stomachs were examined in order to determine the extent to which crayfish are utilized as food. Stomachs were removed from all fish caught by anglers during August and September of 1962, and from April to September in 1963. During the other months of the year fish were collected with a d-c electrofishing device or by hook and line. Collections were made at intervals not greater than two months. Each item was identified, weighed and its volume in milliliters determined by water displacement. A total of 273 stomachs were examined between August 1962 and September 1963. Since the population during this sampling period did not exceed 600 fish this sample represents a major portion of the fish in the lake. Further details are available in Momot (1965).

The rate of consumption of crayfish by trout was obtained from empirical observations. This rate was then related to the size of the stock of crayfish, and the numbers and sizes of the predators. The equilibrium yield, defined as the yield by weight taken from crayfish stock when it is in equilibrium with predation of a given intensity, and its density is not changing from one year to the next apart from effects of environmental variation, was calculated for females and males of the population, under various rates of predation, by substituting predation rates for fishing mortality in the equation for yield given by Ricker (1958). This determined the rate of predation by trout that would yield the greatest production of crayfish. It also measured the theoretical resiliency of the crayfish stock to increased exploitation by the trout. The expression for calculating the equilibrium yield is:

$$
\mathbf{Y}_{\mathbf{E}}=\sum_{\mathbf{T}=\mathbf{T}_{\mathbf{R}}}^{\mathbf{T}=\mathbf{T}} \mathbf{p}_{\mathbf{T}} \overline{\mathbf{W}}_{\mathbf{T}},
$$

Where $T=$ successive intervals or periods in the life of the crayfish,

$\mathrm{T}_{\mathrm{R}}=$ the first period under consideration,

$\mathrm{T}=$ the last period under consideration,

$\bar{W}=$ average weight of the stock, $p=$ instantaneous rate of fishing mortality, and

$Y_{E}=$ equilibrium yield.

\section{EFFECTS OF PREDATION BY BROOK TROUT}

Only the larger fish preyed upon crayfish. The smallest trout containing a crayfish was $196 \mathrm{~mm}$ in total length and only 4 of 29 fish that contained crayfish were less than 229 $\mathrm{mm}$ in total length. Accordingly, all the trout used in the calculation of monthly predation rates had a minimum length arbitrarily set at $229 \mathrm{~mm}$.

Predation rates were assessed as follows: Estimates of the number of fish having a length greater than $229 \mathrm{~mm}$ were made in the autumns of 1962 and 1963 and in the spring of 1963 by the staff of the Pigeon River Trout Research Station. The Petersen mark-andrecapture method was employed. These estimates give the total instantaneous mortality rate (i) for the period October 1962 to October 1963. The instantaneous fishing mortality rate $(p)$, known from creel census records, was subtracted from the total instantaneous mortality rate $(i)$ to give the natural instantaneous mortality rate $(q)$ (Ricker, 1958). The percentage of each year class $229 \mathrm{~mm}$ in length or longer, present in the lake, was determined by a graphical method (Allen, 1954). This method estimates the proportion of a year class that is of a certain minimum size. It is constructed by plotting the size-frequency distribution of fish of the same age on normal probability paper (Figure 1). If the distribution is normal then such a plot is a straight line. One also needs to know the relative deviation (standard deviation divided by the mean) of the size distribution of fish of a given age. A relative deviation of 0.11 taken from a brook trout population study in Wisconsin (McFadden, 1961) was used in calculating values in the nomograph. Most natural salmonid populations have a relative deviation around 0.10 when size-frequency plots are constructed (McFadden, personal communication). In the construction of the nomograph one plots the mean length determined from the size-frequency distribution on the $50 \%$ frequency ordinate of normal probability paper and a length less than the 


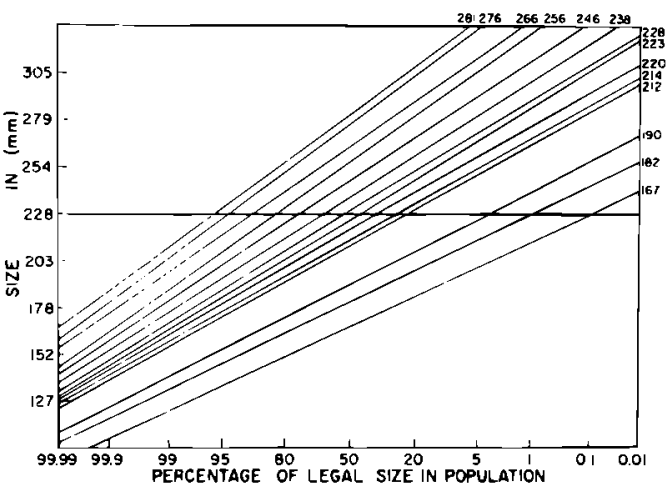

Ficure 1.-Relationship of mean length of a year class to the percentage of fish over 9 inches in length. Based on a relative deviation of 0.111 . Right hand vertical scale gives the mean length of the fish population sample.

mean by the amount of the relative deviation on the $15.9 \%$ frequency ordinate. These points are then connected with a straight line.

In using Figure 1 the mean length of the sample of the fish population is located on the right hand vertical scale. The corresponding diagonal line is followed to the left to the point of intersection with the horizontal line corresponding to a given minimum size limit on the left hand vertical scale (in this case $229 \mathrm{~mm}$ ). By following a vertical line downward from this point of intersection to the lower horizontal scale one obtains the percentage of the population which is of a given size i.e., greater than the minimum size limit of $229 \mathrm{~mm}$. This method permitted calculation of the number of predator trout (those longer than $229 \mathrm{~mm}$ at any given time) if the mean length of the fish in the lake at that time was known.

Monthly estimates of the number of predator trout in the lake were multiplied by the average number of crayfish eaten in one day by predator trout (Table 1) to give the total number of crayfish eaten each month by the trout. This figure was divided by a digestion factor calculated from data given by Hess and Rainwater (1939) and Phillips et al. (1960) to correct for differences in digestion rates of crayfish at various lake temperatures. Unpublished data of G. Alexander (personal communication) for brown trout tend to substantiate my estimated digestion rates for the
TaBle 1.-Estimates of the number of crayfish consumed each month from August 1962 to November 1963 by trout larger than $229 \mathrm{~mm}$

\begin{tabular}{lccccr}
\hline $\begin{array}{c}\text { Month and } \\
\text { year }\end{array}$ & $\begin{array}{c}\text { Number } \\
\text { of trout } \\
\text { larger } \\
\text { than } \\
\mathbf{2 2 9} \\
\text { mm }\end{array}$ & $\begin{array}{c}\text { Average } \\
\text { numbers } \\
\text { of cray- } \\
\text { fish con- } \\
\text { sumed } \\
\text { per day }\end{array}$ & $\begin{array}{c}\text { Diges- } \\
\text { tion } \\
\text { rate } \\
\text { factor }\end{array}$ & $\begin{array}{c}\text { Num- } \\
\text { ber } \\
\text { of } \\
\text { days }\end{array}$ & $\begin{array}{c}\text { Total } \\
\text { crayfish } \\
\text { con- } \\
\text { sumed }\end{array}$ \\
\hline $\begin{array}{l}\text { 1962 } \\
\text { August }\end{array}$ & 122 & 46 & 1 & 31 & 1,426 \\
September & 108 & 52 & 1 & 30 & 1,551 \\
October & 108 & 0 & 2 & 30 & 0 \\
Nov-Dec & 129 & 28 & 2 & 61 & 866 \\
l963 & & & & & \\
Jan-Feb & 94 & 82 & 4 & 59 & 1,204 \\
March & 86 & 172 & 4 & 31 & 1,333 \\
April & 64 & 37 & 2 & 30 & 557 \\
May-June & 79 & 0 & 2 & 61 & 0 \\
July & 110 & 60 & 1 & 31 & 1,875 \\
August & 116 & 21 & 1 & 31 & 648 \\
September & 109 & 50 & 1 & 30 & 1,503 \\
Oct-Nov & 104 & 0 & 2 & 61 & 0 \\
\hline
\end{tabular}

1 Estimated number of days required to digest one crayfish at the temperature of the environment during the month indicated. This factor was obtained from the percentage of natural food items remaining in the stomachs of trout held at various temperatures as determined by Hess and of food through the trout intestine as observed by Phillips et al. $(1960)$.

sizes of fish and crayfish involved in this part of the study. From these data mortality due to trout predation and the contribution of a given year class of crayfish to the food of the trout were estimated for each month of the year (Table 1).

Trout were effective predators only on the 1/2-1-year-old crayfish. Apparently crayfish more than a year old were too large to be captured by the trout. The seasonal pattern of predation by the trout reflects this selection.

During the winter months the lack of emerging insects, of major importance in the trout's diet during early summer (Figure 2), intensifies predation upon the crayfish.

At this time the young-of-the-year crayfish weigh $0.73 \mathrm{~g}$ and are at the optimum size for trout. Consumption of crayfish declined abruptly in April; by June most of the yearlings were larger than $21 \mathrm{~mm}$, in carapace length which is the upper size limit of crayfish eaten by brook trout (Momot, 1965).

In June, young-of-the-year had not yet hatched and were unavailable to trout. From July to November, though many crayfish were eaten, the weight consumed did not equal that of the winter period. In July, an average of 60 crayfish averaging $6 \mathrm{~mm}$ in carapace length were eaten each day compared to 43 


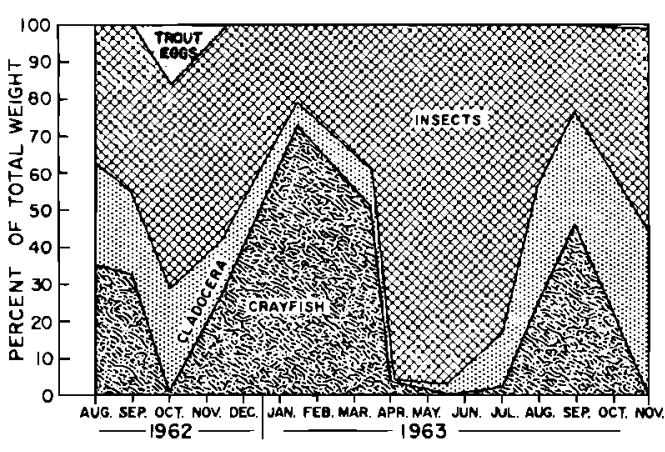

Frcune 2.-Percentage of various food items (by weight) making up the stomach contents of brook trout 5 to 14 inches long. Data summarized at monthly intervals 1962-1963. A total of 239 stomaclis were examined.

per day with an average carapace length of $21 \mathrm{~mm}$ in March. In terms of weight, the consumption dropped from a peak of $30 \mathrm{~g}$ per day in March to 0.4 $\mathrm{g}$ per day in April. From October through November there were no crayfish in the stomachs examined, but trout eggs appeared. Perhaps the trout eggs buffered crayfish predation during this period.

Maximum utilization of crayfish by the brook trout occurred in midwinter and late summer, with little or no consumption in early spring and late fall. Only the young were eaten.

The fraction of crayfish utilized as food by trout was obtained by dividing estimated number of young-of-the-year crayfish consumed during a given time interval by the difference between the number of crayfish present at the beginning and at the end of the interval. Estimates of the size of the crayfish population were made using the Schumacher mark and recapture method. Young crayfish were easily collected by seining along the shore after dark with a minnow seine of $0.635 \mathrm{~cm}$ mesh. Each collection of young crayfish consisted of a series of seine hauls which extended around the entire circumference of the lake. The young of $O$. virilis remain near the shore in contrast with adults which are distributed throughout the lake.

Crayfish were marked by clipping the pleuron with a pair of fine pointed scissors, a technique developed and described by Goellner (1943).
Experiments carried out to validate these procedures are described in Momot (in press). For example, there were as estimated 189,530 young-of-the-year crayfish (obtained by multiplying the average number of attached eggs per female $\times$ the number of adult females in the population) produced in the spring of 1963. By the end of that summer, this number declined to an estimated 12,000 individuals consisting of 5,772 males, 95\% confidence limits of $4,819-7,220$ and 7,128 females with $95 \%$ confidence limits of 5,900 9,050 (Momot, in press). This represents a total mortality from July to September of 176,630 . Of this number, 4,026 were estimated to have been eaten by the trout (Table 1). Thus trout predation between July and October accounted for $2.3 \%$ of the total mortality of young-of-the-year crayfish.

Similarly it accounts for $56 \%$ of the total mortality of young-of-the-year crayfish between October and June. Out of a total standing crop of $150.2 \mathrm{~kg}$ present in the summer of $1962,18.4 \mathrm{~kg}$ (age-0) was available as trout food (Figure 3). In the spring of 1963 , $12.4 \mathrm{~kg}$ out of a total crop of $179.1 \mathrm{~kg}$ was available and in the summer of 1963 , only $9.4 \mathrm{~kg}$ out of 137.6 was of proper size. Hence, almost twice as many crayfish were available as trout food in the summer of 1962 than in the summer of 1963. In the summer of 1963 less than $0.9 \mathrm{~kg}$ of the $9.4 \mathrm{~kg}$ available was actually consumed by trout (Figure 3 ). Even though winter predation accounted for $56 \%$ of the total mortality from October to June, this amounted to only $16 \%$ of the total available population. The annual net production of crayfish in West Lost Lake was estimated at $310.8 \mathrm{~kg}$, about 2.3 times the summer standing crop (Momot, in press). The net production is the sum of the weight at the time of mortality of all animals dying during the year. This was determined by multiplying the number of crayfish dying between intervals by the average weight of the crayfish of the appropriate size during that interval. The numbers of crayfish of a given age that were alive at subsequent intervals were determined by sequential population estimates (Momot, in press). On an annual basis, trout utilized only $2.9 \%$ of the total net production of 


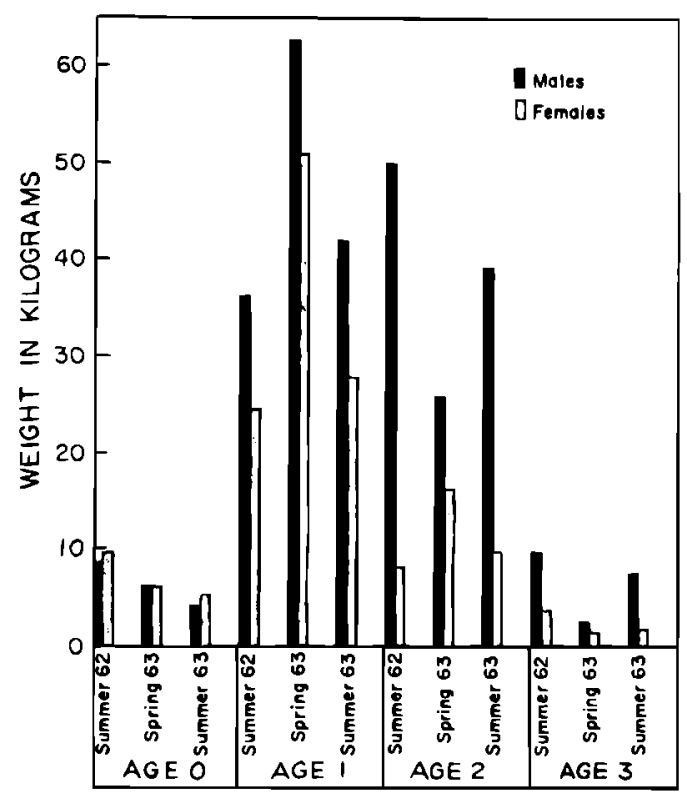

Ficure 3.-Weight of crayfish of various age groups in West Lost Lake during 1962 and 1963.

crayfish biomass in the lake and only $4.2 \%$ of the available net production i.e., young-ofthe-year considered alone. Thus we have a low rate of flow of energy from one important trophic level to another. This constitutes an important bottleneck in the energy flow as it pertains to the trophic level of most importance to man. The trout is therefore an ineffective predator and a minor factor in controlling population size of crayfish in the lake.

If trout larger than the present $126 \mathrm{~mm}$ length were stocked, utilization of the crayfish would be increased since trout would reach an effective predator length $(229 \mathrm{~mm})$. Orconectes propinquus, a smaller species of crayfish $(17 \mathrm{~mm}$ at maturity vs. $25 \mathrm{~mm}$ for $O$. virilis) might be introduced and would provide food of the proper size for its entire life span. However, this species might be less resilient to predation than $O$. virilis because only one brood per generation is produced (Van Deventer, 1937). Another possibility is to stock a species of fish that would eat large adult crayfish.

Predation by brook trout influenced the age distribution of the population. Since juveniles rather than adults were eaten by trout, the crayfish population responded by adjusting its survivorship distribution rather than through a change in fecundity. To study the resiliency of the crayfish population to trout predation, calculations of equilibrium yield were made for a series of theoretical predation rates. Ricker's (1958) formula was used for estimation of equilibrium yield at different rates of fishing (predation rates). This formula is applicable when growth and mortality rates are reasonably constant during a given time period. It was necessary to break the population down into time intervals meeting this requirement. Calculations of yields were made for age-0 (young-of-theyear) females and males since these age groups make up the total available population eaten by trout. In addition, the number of surviving females has a significant influence upon population stability. Since mortality rates were higher during the second half of the first year, young-of-the-year females and males were each divided into two age groups, viz. those less than 6 months old and those more than 6 months old. In these calculations various multiples of the empirically determined predation rate were added to the instantaneous mortality rates of each of these two groups for each sex (cf. Ricker, 1958, p. 211). This gave a series of weight change factors which could be used to calculate yields from each kilogram of female and male recruits at age-II (Table 2) subject to different rates of predation. Age II is the age at which crayfish become mature.

These calculations indicate that a predation rate twice the present rate would result in the maximum equilibrium yield of female and male crayfish to the trout population. A twofold increase in predation would increase the total yield of female and male young-of-theyear crayfish by $33 \%$ under the observed conditions. At a density between 200 and 300 fish both the male and female recruitment would begin to decline from its maximum yield the reason being that mortality of crayfish more than 6 months old would theoretically be $100 \%$. Actually, when the availability of an important food item declines, fish change their feeding habits (Ivlev, 1961), so it is doubtful that extinction through predation 
TABLE 2.-Equilibrium yield of female crayfish at varying rates of predation by brook trout $229 \mathrm{~mm}$ or more in length

\begin{tabular}{|c|c|c|c|c|c|}
\hline $\begin{array}{c}\text { Rate } \\
\text { of } \\
\text { preda- } \\
\text { tion } \\
(p)^{1}\end{array}$ & $\begin{array}{l}\text { Size of } \\
\text { pred- } \\
\text { ator } \\
\text { popu- } \\
\text { lation }\end{array}$ & $\begin{array}{c}\text { Yield of } \\
\text { females } \\
\text { in kilo- } \\
\text { grams } \\
\text { per kilo- } \\
\text { gram } \\
\text { female } \\
\text { recruits } \\
\text { at age-II }\end{array}$ & $\begin{array}{l}\text { Yield of } \\
\text { males } \\
\text { in kilo- } \\
\text { grams } \\
\text { per kilo- } \\
\text { gram } \\
\text { male } \\
\text { recruits } \\
\text { at age-1I }\end{array}$ & $\begin{array}{l}\text { Total } \\
\text { yield } \\
\text { in kilo- } \\
\text { grams per } \\
\text { kilogram } \\
\text { recruits } \\
\text { at age-ll }\end{array}$ & $\begin{array}{l}\text { Yield in } \\
\text { grams } \\
\text { per indi- } \\
\text { vidual } \\
\text { predator }\end{array}$ \\
\hline $\begin{array}{r}0.5 \\
1.0 \\
2.0 \\
3.0 \\
4.0 \\
5.0 \\
6.0 \\
7.0 \\
8.0 \\
10.0\end{array}$ & $\begin{array}{r}50 \\
100 \\
200 \\
300 \\
400 \\
500 \\
600 \\
700 \\
800 \\
1,000\end{array}$ & $\begin{array}{r}3.9 \\
7.9 \\
11.0 \\
8.7 \\
7.0 \\
6.0 \\
5.0 \\
4.4 \\
3.5 \\
1.8\end{array}$ & $\begin{array}{r}7.9 \\
9.1 \\
10.8 \\
9.3 \\
7.0 \\
5.0 \\
4.5 \\
2.9 \\
2.5 \\
2.1\end{array}$ & $\begin{array}{r}11.8 \\
17.0 \\
21.8 \\
18.0 \\
14.0 \\
11.0 \\
9.5 \\
7.3 \\
6.0 \\
3.9\end{array}$ & $\begin{array}{r}23.4 \\
16.9 \\
10.8 \\
5.9 \\
3.5 \\
2.2 \\
1.6 \\
1.4 \\
0.7 \\
0.3\end{array}$ \\
\hline
\end{tabular}

${ }^{1} p$ is the instantaneous rate of mortality due to predation of brook trout. A value of $p$ of 0.06 was used for the 0 to 0.5 age group females and 0.63 for males and a value of 0.47 was used for the 0.5 to 1.0 age group females and 0.46 for males. The instantaneous mortality rate due to predation ( $p$ ) was calculated from the data of Table 1 .

would occur. The yield per individual, if equally divided among all the $229 \mathrm{~mm}$ or larger fish present in the population, declines from $17 \mathrm{~g}$ per individual at present rates of predation to $11 \mathrm{~g}$ per individual at the 200 fish level. At a density of 50 fish, one half the present population, the yield per individual is $23 \mathrm{~g}$. By doubling the present predator population the yield per trout would fall below the maximum but total yield could be increased.

The above estimates require the following assumptions: (1) growth of the crayfish and trout are not dependent upon their respective population densities; (2) crayfish reproduction rates are not substantially altered by changes in crayfish population density; (3) predation remains proportional to density of predators; and (4) changes in rate of predation do not influence mortality from other causes. The latter is unlikely since studies of commercially exploited fish populations indicate that increase in exploitation usually substitutes for other types of mortality. The fish predation in this study is treated as similar in nature to human predation (exploitation) of fish populations. Even though some of the other assumptions may not be met, these calculations suggest that the population could withstand much more trout predation than it presently receives.
Since trout predation accounts for only a small fraction of the mortality of crayfish in these lakes, other possible sources should be considered. Possible predators, such as dragonfly nymphs, small frogs and water snakes do not eat large crayfish but may prey upon the young; however, none of these forms were very abundant and probably would not limit the size of the crayfish population. The painted turtle, Chrysemys picta marginala is abundant but is not considered an important predator on crayfish (Lagler, 1944). Two adult Orconectes virilis were found in a collection of 33 large green frogs, Rana clamilans, from West Lost Lake. This was the only abundant large frog in the lake. Fish-eating birds (e.g., mergansers, herons, etc.) are never abundant during the summer and the narrow shoal area probably limits predation by mammals and birds during the open water season. Ice cover prevents predation by birds and mammals during the winter. In general, population size does not appear to be regulated by predators.

Observations made on West Lost Lake and in the laboratory indicate that molting has an important influence upon mortality rates. Suclden decreases in abundance of certain age groups followed molting. Behavior at the time of molting together with certain physiological and mechanical problems associated with molting may be much more important (Momot, in press).

The crayfish biomass in West Lost Lake was probably near the food-producing capacity of the environment. This was indicated by the small change in biomass between summer 1962 and summer 1963 (Figure 3). Much of the energy flowing into the crayfish popu. lation is not being passed on to a higher trophic level (trout) but is returned to the lake by decomposition or is used by the popu. lation itself (cannibalism).

Studies of the population dynamics of major food organisms of game and food fishes offer many possibilities for improving the yield and production of fish populations. Most of the present attempts to manage the production of aquatic communities, such as fish ponds, and channel the results for human benefit, are based on empirical methods of 
manipulating stocking ratios of fish (Swingle and Smith, 1941). Such efforts even when beneficial can rarely be explained or understood. A knowledge of the effects of preda. tion upon the vital characteristics of the prey populations offers an analytical approach to the task of harnessing productivity for man's benefit. This type of information can be used to increase the efficiency of predator-prey relationships in aquatic ecosystems.

In terms of reproductive capacity of the crayfish population, the effect of a trout eating six young-of-the-year is equivalent to its eating one adult female. ${ }^{3}$ In terms of energy flow to the trout, the results are not equivalent. One adult female weighs $9.3 \mathrm{~g}$, but the six young weigh only $4.2 \mathrm{~g}$. This difference of $5.1 \mathrm{~g}$ could be utilized if a species of fish were introduced that preyed on adults. Also trout probably expend more energy in searching for six young, than one adult female, hence cropping young is less efficient.

Since there is a surplus of old males, and 3 -year-old females contribute only $7.5 \%$ of the total egg production in one season (Momot, in press) increased predation on older adults would probably increase average egg production. This would affect surplus 3-year-old males and not reduce the effective breeding population of females. It would lead to faster growth and better survival of females for there would be less com. petition for food and space from the supernumerary males. Also, among older age groups males weigh more than females, hence, greater yield is achieved by predation on males.

Studies of the comparative population $\mathrm{dy}$ namics of closely related species of benthic invertebrates can be used to disclose those species of benthic invertebrates that have population characteristics which make them valuable as food organisms for fish. The substitution of Orconectes propinquus for $O$. virilis, as proposed in this study, is a good example.

\footnotetext{
394 young/avg. female $\times 0.93$ (the mortality rate of young from hatching until late summer when they become vulnerable to the trout) $=6$ survivors $\times 0.7$ $g$ (the weight of the young by the end of the summer) $=4.2 \mathrm{~g}$ (the weight of young produced by one adult female). Date from an unpublished study available as: Mich. Dept. Cons. Research and Development Report \#42, 71 p.
}

Other possibilities exist not only for crayfish but other aquatic invertebrates.

\section{ACKNOWLEDGMENTS}

The author acknowledges the assistance of the following: Dr. Karl F. Lagler of the University of Michigan for academic counsel; Dr. Frank F. Hooper of the University of Michigan for a detailed review of the manuscript; Dr. James T. McFadden of the University of Michigan for statistical counsel; Dr. Shelby D. Gerking of Indiana University, Drs. Francis C. Evans and John E. Bardach of the University of Michigan and Dr. Gerald P. Cooper of the Michigan Department of Conservation for suggestions on improvement of the manuscript. The following personnel of the Institute assisted in the field work: Dr. W. Carl Latta, Mr. Harry Westers, Mr. Gerald Myers, Mr. Harold Brado, and Mr. Doyle Edson. Mr. Robert Barber helped in the construction of special equipment. Mr. Paul M. Earl prepared all of the graphs.

\section{LITERATURE CITED}

AlLen, K. R. 1954. Factors affecting the efficiency of restrictive regulations in fisheries management. I. Size limits. New Zealand J. Sci. Technol., B., 35: 305-334.

Goellner, K. E. 1943. The life cycle and productivity of the crayfish, Cambarus immunis (Hagen). Doctoral Dissertation, Univ. of Mich., Ann Arbor.

Hess, A. D., and J. H. Rainwater, 1939. A method for measuring the food preference of trout. Copeia 1939: 154-157.

lveev, V. S. 1961. Experimental ecology of the feeding of fishes. Yale Univ. Press. New Haven and London, $302 \mathrm{p}$.

Lacler, K. F., ANd M. J. Lagler. 1944. Natural enemies of crayfishes in Michigan. Pap. Mich. Acad. Sci. Arts. Lett. 29: 293-303.

Latta, W. C. 1962 . Periodicity of morality of brook trout during first summer of life. Trans. Amer. Fish. Soc. 91: 408-411.

_ _ AND G. F. MYers. 1961. Night use of a direct current electric schocker to collect trout in lakes. Trans. Amer. Fish. Soc. 90: 81-83.

McFadden, J. T. 1961. A population study of the brook trout, Salvelinus fontinalis. Wildl. Monogr. No. 7, 73 p.

Moмот, W. T. 1965. Food habits of the brook trout in West Lost Lake. Trans. Amer. Fish. Soc. 94: 188-191.

- Population dynamics and productivity of the crayfish, Orconectes virilis, in a marl lake. Amer. Mid. Nat. (In press.) 
Phillips, A. M., H. A. Podoliak, D. L. Livincton, R. F. HaMmer, AND G. L. HaMmer. 1960. The effect of water temperature and diet on the rate of passage of food through the tract of fingerling brook trout. Cortland Hatchery Rept. No. 29: $55-58$.

Ricker, W. E. 1958. Handbook of computations for biological statistics of fish populations. Bull. Fish. Res. Bd. Canada 119, 300 p.

TanNer, H. A. 1960. Some consequences of adding fertilizers to five Michigan trout lakes. Trans. Amer. Fish. Soc. 89: 198-205.

Swingle, H. S., ANd E. V. Smith. 1941. The management of ponds for the production of game and pan fish, p. 218-226. In A symposium on hydrobiology, University of Wisconsin Press, Madison.

Van Deventer, W. C. 1937. Studies on the biology of the crayfish Cambarus propinquus Girard. Ill. Biol. Monogr. 15: 1-67. 